FOLIA POMERANAE UNIVERSITATIS TECHNOLOGIAE STETINENSIS

Folia Pomer. Univ. Technol. Stetin., Oeconomica 2018, 342(90)1, 5-16

Iwona BĄK

\title{
WYKORZYSTANIE TAKSONOMII WIELOKRYTERIALNEJ DO OCENY SYTUACJI SPOKECZNO-GOSPODARCZEJ KRAJÓW UNII EUROPEJSKIEJ
}

\author{
APPLICATION OF THE MULTICRITERIAL TAXONOMY \\ FOR EVALUATION OF THE SOCIO-ECONOMIC SITUATION \\ OF COUNTRIES OF THE EUROPEAN UNION
}

Katedra Zastosowań Matematyki w Ekonomii, Zachodniopomorski Uniwersytet Technologiczny w Szczecinie, ul. Klemensa Janickiego 31, 71-270 Szczecin, e-mail: iwona.bak@zut.edu.pl

\begin{abstract}
Summary. The aim of the research carried out in the article is to assess the socio-economic situation of the European Union countries and to identify the typological groups of countries similar in terms of the level of development. In the article were used two approaches. The first of them, concern on the classification of countries, separately in the social and economic aspect. For this purpose, the zero-uniformization method was used. In the second approach, the European Union countries were divided into typological groups, similar at the same time in terms of the characteristics characterizing both aspects. In this case, a multi-criteria taxonomy was used. The data for the analysis was taken from the CSO and Eurostat publications. As a result of the conducted research, it turned out that economically well-developed countries are often characterized by unfavorable indicators concerning, for example, the demographic situation, health protection or the labor market.
\end{abstract}

Słowa kluczowe: sytuacja społeczno-gospodarcza, kraje UE, metoda unitaryzacji zerowanej, taksonomia wielokryterialna.

Key words: socio-economic situation, EU countries, zero-uniform unitarization method, multicriteria taxonomy.

\section{WSTĘP}

Jednym z zasadniczych celów Unii Europejskiej jest tworzenie warunków dla zrównoważonego rozwoju całego jej terytorium. Równomierny rozwój państw członkowskich to jeden ze strategicznych kierunków dalszego funkcjonowania Unii, przy czym może i powinien być on rozpatrywany w odniesieniu do wielu obszarów. W równomiernym rozwoju UE można również upatrywać szans na przezwyciężenie negatywnych skutków kryzysu finansowego i gospodarczego z lat 2007-2008 oraz wielu problemów nękających Unię w ostatnich latach. Bezsprzeczną siłą gospodarki unijnej jest ogromny wewnętrzny rynek zapewniający funkcjonowanie obszaru gospodarczego między państwami członkowskimi bez granic wewnętrznych na skalę nieznaną w stosunkach międzynarodowych. Fundamentem tego rynku jest art. 26 TFUE o swobodnym przepływie towarów, usług, osób i kapitału. Jednakże według opinii zarówno eurosceptyków, jak i zwolenników dalszego funkcjonowania Unii Europejskiej ostatnie 10 lat to dla gospodarki i trwałości integracji UE okres bardzo trudny. 
Oprócz wspomnianego już kryzysu ogólnoświatowego mamy w przypadku Unii Europejskiej do czynienia z takimi problemami, jak przewlekła niestabilność finansowa wielu państw członkowskich UE (kryzys zadłużenia i np. groźba opuszczenia przez Grecję strefy euro), napływ uchodźców z Bliskiego Wschodu (kryzys migracyjny i zagrożenie terrorystyczne) i związany z nim kryzys wspólnej polityki zagranicznej, a także najgłośniejszy w ostatnich miesiącach, związany z ostatnimi wydarzeniami w Wielkiej Brytanii i kontrowersyjną decyzją społeczeństwa tego kraju o opuszczeniu Unii Europejskiej (tzw. brexit), kryzys zagrażający spójności i integracji Unii Europejskiej.

Jako przyczyny tych negatywnych zmian wskazuje się wiele czynników: od błędów w polityce makroekonomicznej Unii po problemy społeczno-demograficzne związane $\mathrm{np}$. ze starzeniem się społeczeństw niektórych krajów Unii, najczęściej najbardziej rozwiniętych (np. Niemiec). Sporym zagrożeniem są również ogólnoświatowe procesy globalizacyjne, obejmujące w szczególności: narastające nierówności, ubóstwo, marginalizację całych społeczeństw, brak poszanowania środowiska przyrodniczego czy w ogóle niedoskonałość liberalnego modelu światowej gospodarki, zakładającą, że wzrost ekonomiczny jest źródłem postępu, w tym także społecznego (Bąk i in. 2017).

Celem artykułu jest próba oceny sytuacji społeczno-gospodarczej krajów Unii Europejskiej.

\section{MATERIA I METODA}

Do oceny sytuacji społeczno-gospodarczej krajów UE zebrano wstępnie dane statystyczne dotyczące 24 cech charakteryzujących aspekty społeczne i 22 cech odnoszących się do aspektów gospodarczych. Wybór cech zdeterminowany był dostępnością danych. Większość informacji pochodziła z 2016 roku; jedynie w kilku przypadkach, z uwagi na brak danych, zdecydowano się na lata wcześniejsze ${ }^{1}$. Do cech diagnostycznych charakteryzujących aspekty społeczne zaliczono:

$X_{1}$ - urodzenia żywe na 1000 ludności;

$X_{2}$ - zgony na 1000 ludności;

$X_{3}$ - zgony niemowląt na 100 urodzeń żywych;

$X_{4}$ - współczynnik przyrostu naturalnego, w promilach;

$X_{5}$ - przeciętne trwanie życia mężczyzn, w latach;

$X_{6}$ - przeciętne trwanie życia kobiet, w latach;

$X_{7}$ - ofiary śmiertelne w wypadkach drogowych na 1 mln ludności;

$X_{8}$ - małżeństwa na 1000 ludności;

$X_{9}$ - rozwody na 1000 ludności;

$X_{10}$ - ludność w wieku 65 lat i więcej, w \% ogółu ludności;

$X_{11}$ - młodzież w wieku 18-24 lata niekontynująca nauki, w \% ogółu ludności w tej grupie wiekowej;

$X_{12}$ - osoby w wieku 30-34 lata posiadające wykształcenie wyższe, w \%;

\footnotetext{
${ }^{1}$ Dane pochodziły z bazy danych Eurostatu (dostęp: 24.04.2018) oraz z publikacji GUS (Rocznik Statystyki Międzynarodowej 2017).
} 
$X_{13}$ - studenci szkół wyższych na 10 tys. ludności;

$X_{14}$ - liczba ludności na 1 lekarza;

$X_{15}$ - liczba ludności na 1 lekarza stomatologa;

$X_{16}$ - liczba ludności na 1 farmaceutę;

$X_{17}$ - liczba ludności na 1 pielęgniarkę;

$X_{18}$ - łóżka szpitalne na 100 tys. ludności;

$X_{19}$ - poszkodowani w wypadkach śmiertelnych przy pracy na 100 tys. pracujących;

$X_{20}$ - wskaźnik cen towarów i usług konsumpcyjnych w 2016 roku $(2010=100)$;

$X_{21}$ - wskaźnik zagrożenia ubóstwem lub wykluczeniem społecznym, w \%;

$X_{22}$ - wskaźnik zagrożenia ubóstwem po uwzględnieniu w dochodach transferów społecznych, w \%;

$X_{23}$ - wskaźnik bardzo niskiej intensywności pracy w gospodarstwie domowym, w \%;

$X_{24}$ - wskaźnik pogłębionej deprywacji materialnej, w \%.

Aspekty gospodarcze scharakteryzowano za pomocą następujących cech:

$X_{1}$ - wskaźnik zatrudnienia osób w wieku 15-64 lata, w \%;

$X_{2}$ - wskaźnik zatrudnienia kobiet w wieku 15-64 lata, w \%;

$X_{3}$ - wskaźnik zatrudnienia osób w wieku 20-64 lata;

$X_{4}$ - stopa bezrobocia, w \%;

$X_{5}$ - stopa bezrobocia osób w wieku 15-24 lata, w \%;

$X_{6}$ - stopa bezrobocia długookresowego, w \%;

$X_{7}$ - udział bezrobotnych powyżej 12 miesięcy, w \% wszystkich bezrobotnych;

$X_{8}$ - udział bezrobotnych pozostających bez pracy do 3 miesięcy, w \% wszystkich bezrobotnych;

$X_{9}$ - osoby bezrobotne w wieku 15-24 lata, w \% osób w tej samej grupie wieku;

$X_{10}$ - udziału bezrobotnych z wykształceniem wyższym w ogólnej liczbie bezrobotnych, w \%;

$X_{11}$ - wydajność pracy wyrażonej jako PKB na 1 pracującego;

$X_{12}$ - liczba pracujących na 1000 ludności;

$X_{13}$ - koszty pracy, w EUR/godz.;

$X_{14}$ - PKB na 1 mieszkańca, w USD;

$X_{15}$ - dług sektora instytucji rządowych i samorządowych, w \% PKB;

$X_{16}$ - zadłużenie sektora prywatnego, w \% PKB;

$X_{17}$ - nakłady na działalność badawczo-rozwojową, w \% PKB;

$X_{18}$ - udział energii ze źródeł odnawialnych w końcowym zużyciu energii brutto, w \%;

$X_{19}$ - wskaźnik emisji gazów cieplarnianych w 2016 roku $(2000=100)$;

$X_{20}$ - odpady komunalnych wytworzonych na 1 mieszkańca, w kg;

$X_{21}$ - wpływy z turystyki na 1 mieszkańca, w USD;

$X_{22}$ - wydatki na turystykę na 1 mieszkańca, w USD.

Z uwagi na cel artykułu w badaniu zastosowano dwa podejścia. Pierwsze z nich dotyczyło klasyfikacji krajów Unii Europejskiej w dwóch aspektach - społecznym i gospodarczym. Liniowe porządkowanie krajów przeprowadzono za pomocą taksonomicznego miernika rozwoju opartego na metodzie unitaryzacji zerowanej. W drugim podejściu dokonano podziału krajów UE na grupy typologiczne podobne jednocześnie pod względem stanu 
rozwoju społeczno-gospodarczego. Wykorzystano do tego taksonomię wielokryterialną. Punktem wyjścia $\mathbf{w}$ tej metodzie są macierze odległości $\mathbf{D}^{\mathbf{K}}$ o elementach $d_{i j}^{k}$, wyznaczone odrębnie dla poszczególnych kryteriów (w badaniu $K=2$ ). Przed obliczeniem odległości konieczne jest doprowadzenie cech do możliwości ich porównania, czyli pozbawienie ich mian i ujednolicenie rzędów wielkości (Walesiak 2011). Ze względu na fakt, że w ostatecznym zbiorze cech diagnostycznych znalazły się cechy zmierzone na skali przedziałowej i ilorazowej, zdecydowano się na ich normalizację z wykorzystaniem metody unitaryzacji zerowanej według formuły Kukuły (2000):

- dla stymulant

$$
z_{i j}=\frac{x_{i j}-\min _{i} x_{i j}}{\max _{i} x_{i j}-\min _{i} x_{i j}} \quad \max _{i} x_{i j} \neq \min _{i} x_{i j}
$$

- dla destymulant

$$
z_{i j}=\frac{\max _{i} x_{i j}-x_{i j}}{\max _{i} x_{i j}-\min _{i} x_{i j}} \quad \max _{i} x_{i j} \neq \min _{i} x_{i j}
$$

Z każdej macierzy odległości wyznaczono wartość progową odległości $d^{*}$ według wzoru:

$$
d^{*}=\min _{i} \max _{j}\left\{d_{i j}\right\}
$$

Następnie dla każdego kryterium klasyfikacji (aspektu społecznego i gospodarczego) zbudowano macierz podobieństwa $\mathbf{C}^{\mathbf{K}}$ o wymiarach $(n \times n)^{2}$, która jest macierzą zerojedynkową, utworzoną według zasady $(i, j=1,2, \ldots, n ; n$ - liczba krajów):

$$
\begin{aligned}
& c_{i j}^{K}=1 \text { dla } d_{i j} \leq d^{*} \\
& c_{i j}^{K}=0 \text { dla } d_{i j}>d^{*}
\end{aligned}
$$

Za podobne ze względu na rozpatrywane kryterium uznaje się obiekty o numerach $i$ oraz $j$, dla których spełniona jest nierówność $d_{i j} \leq d^{*}$; w przeciwnym wypadku obiekty traktowane są jako niepodobne; dla nich miara podobieństwa $c_{i j}$ jest równa zeru.

W kolejnym kroku wyznaczono finalną macierz podobieństwa między analizowanymi obiektami $\mathbf{C}_{(n \times n)}$. Elementy tej macierzy $\left(c_{i j}\right)$ są równe iloczynowi odpowiednich elementów macierzy $\mathbf{C}^{\mathrm{K}}$ dla obu rozpatrywanych aspektów, czyli:

$$
c_{i j}=\prod_{K=1}^{2} c_{i j}^{K}
$$

Oznacza to, że powyższy iloczyn jest równy jeden, jeżeli każdy z odpowiadających mu elementów $c_{i j}^{K}$ w macierzach $\mathbf{C}^{\mathbf{K}}$ jest równy jedności. Natomiast gdy przynajmniej jeden z elementów $c_{i j}^{K}$ jest równy zeru, iloczyn wynosi zero. Zgodnie z powyższym dwa obiekty uznaje się za podobne do siebie ze względu na wszystkie kryteria, jeśli są do siebie podobne oddzielnie według poszczególnych kryteriów. Natomiast dwa obiekty uznaje się za niepodobne, jeśli nie są podobne do siebie chociażby ze względu na jedno z kryteriów.

W celu identyfikacji grup obiektów podobnych ze względu na oba rozpatrywane kryteria wykorzystano metodę eliminacji wektorów (Chomątowski i Sokołowski 1978; Panek 2009;

\footnotetext{
2 Dla aspektów społecznych macierz podobieństwa ma wymiary $12 \times 12$, natomiast dla aspektów gospodarczych $-10 \times 10$.
} 
Malina 2004). Punktem wyjścia tej metody jest zamiana finalnej macierzy podobieństwa $\mathbf{C}_{(n \times n)}$ W macierz braku podobieństw $\mathbf{C}_{(n \times n)}^{*}$; grupowanie przebiega w następujący sposób:

1) na podstawie macierzy $\mathbf{C}^{*}$ tworzy się wektor kolumnowy $\boldsymbol{c}_{0} \circ n$ składowych, $z$ których każda jest sumą odpowiedniego wiersza tej macierzy;

2) z macierzy $\mathbf{C}^{*}$ eliminuje się ten wiersz, i odpowiadającą mu kolumnę, dla którego wartość składowa wektora $\boldsymbol{c}_{0}$ jest maksymalna; jeśli wektor $\boldsymbol{c}_{0}$ zawiera kilka składowych o wartości równej wartości maksymalnej, to eliminujemy wiersz i kolumnę, na przykład o najmniejszym lub o największym numerze;

3) czynności przedstawione w punktach 1) i 2) powtarzamy, aż wszystkie składowe wektora $c_{0}$ będą równe zero;

4) obiekty odpowiadające nieskreślonym wierszom i kolumnom, które pozostały w macierzy $\mathrm{C}^{*}$, tworzą pierwszą podgrupę;

5) dla pozostałych obiektów (wyeliminowanych we wcześniejszych etapach) tworzy się okrojoną macierz $\mathbf{C}^{*}(\mathbf{1})$ i wektor $\boldsymbol{c}_{0}(1)$, a następnie, przeprowadzając postępowanie opisane w punktach 1) do 4), otrzymuje się kolejne grupy obiektów podobnych. Postępowanie kończy się w momencie, gdy wszystkie jednostki ze zbioru podstawowego zostaną pogrupowane.

\section{WYNIKI}

Do liniowego porządkowania krajów Unii Europejskiej, oddzielnie w dwóch aspektach społecznym i gospodarczym, wykorzystano miernik rozwoju oparty na unitaryzacji zerowanej. Prawidłowa konstrukcja miernika wymaga wyboru cech diagnostycznych o wysokich walorach dyskryminacyjnych (Młodak 2006). Dlatego w pierwszym etapie z badania wykluczono te cechy, które charakteryzowały się względnym zróżnicowaniem wynoszącym poniżej $10 \%$. W kolejnym kroku, badając podobieństwo za pomocą współczynników korelacji, zauważono występowanie bardzo silnej zależności między niektórymi cechami. W celu wyeliminowania cech o podobnym potencjale informacyjnym (silnie ze sobą skorelowanych) zastosowano metodę odwróconej macierzy ${ }^{3}$. Doprowadziło to do uzyskania finalnych zbiorów cech diagnostycznych (tab. 1). Znalazły się wśród nich zarówno stymulanty, których duże wartości są korzystne z punktu widzenia istoty analizowanego zjawiska, oraz destymulanty, w przypadku których pożądane są wartości małe.

Tabela 1. Podział cech diagnostycznych na stymulanty i destymulanty - aspekty społeczne i gospodarcze

\begin{tabular}{|c|c|c|c|}
\hline \multicolumn{2}{|c|}{ Aspekt społeczny } & \multicolumn{2}{c|}{ Aspekt gospodarczy } \\
\hline stymulanty & destymulanty & stymulanty & destymulanty \\
\hline$X_{4}, X_{8}, X_{10}, X_{12}, X_{13}, X_{18}$ & $X_{9}, X_{15}, X_{16}, X_{19}, X_{21}, X_{23}$ & $X_{1}, X_{18}, X_{21}$ & $X_{4}, X_{6}, X_{10}, X_{15}, X_{16}, X_{19}, X_{20}$ \\
\hline
\end{tabular}

Wykorzystując metodę unitaryzacji zerowanej, wyznaczono dwa rankingi państw członkowskich UE oraz grupy typologiczne obiektów podobne pod względem aspektów społecznych i gospodarczych (tab. 2). Jak wynika z tab. 2, kraje UE są bardzo zróżnicowane pod względem pozycji zajmowanych w rankingach. Tylko Austria została sklasyfikowana na

\footnotetext{
${ }^{3}$ Opis metody można znaleźć np. w pracach: Nowak (1990); Malina (2004); Młodak (2006); Panek (2009).
} 
tym samym miejscu (siódmym) zarówno pod względem aspektów społecznych, jak i gospodarczych. W przypadku pięciu państw (Chorwacji, Danii, Hiszpanii, Irlandii i Portugalii) różnica w zajmowanych pozycjach wynosiła jeden; w przypadku siedmiu krajów różnica wynosiła przynajmniej 12. Największą rozbieżność zauważa się w przypadku Rumunii, która zajęła 3 pozycję pod względem aspektów gospodarczych i 28 pod względem aspektów społecznych. Kraj ten wyróżniał się pozytywnie, jeśli chodzi o wskaźniki na rynku pracy (niska stopa bezrobocia ogółem i wskaźnik długookresowy), wysoki udział energii ze źródeł odnawialnych w końcowym zużyciu energii brutto, mała ilość odpadów komunalnych oraz niskie zadłużenie sektora prywatnego i sektora instytucji rządowych oraz samorządowych (w \% PKB). Na ostatnie miejsce Rumunii, w rankingu z uwagi na aspekty społeczne, wpływ miały przede wszystkim: najniższy w UE udział osób z wyksztalceniem wyższym w wieku 30-34 lata w ogólnej liczbie ludności w danej grupie wiekowej, najwyższy w UE wskaźnik poszkodowa-nych w wypadkach śmiertelnych przy pracy na 100 tys. pracujących, wysoki wskaźnik zagrożenia ubóstwem i wykluczeniem społecznym oraz ujemny przyrost naturalny.

Polska ze względu na aspekty społeczne znalazła się dopiero na 17 pozycji w trzeciej grupie, wraz z Luksemburgiem, Węgrami, Chorwacją, Wielką Brytanią, Słowacją, Holandią i Bułgarią. Negatywny wpływ na sytuację społeczną w tej grupie miały przede wszystkim: niski wskaźnik przyrostu naturalnego (z wyjątkiem Luksemburga), niższa od przeciętnej w krajach UE liczba studentów na 10 tys. ludności oraz najwyższa wśród grup średnia dotycząca liczby ludności na 1 lekarza stomatologa. Ponadto grupa ta wyróżniała się pozytywnie dużą liczbą łóżek szpitalnych na 100 tys. ludności (10\% powyżej średniej unijnej) oraz najniższym przeciętnym wskaźnikiem bardzo niskiej intensywności pracy w gospodarstwie domowym. Dla porównania: kraje zaliczone do pierwszej grupy (najlepszej) charakteryzowały się m.in. niskimi wskaźnikami zagrożenia ubóstwem, wysokim przyrostem naturalnym w większości krajów z tej grupy, dużą liczbą zawieranych małżeństw na 1000 ludności oraz wysokim udziałem osób z wykształceniem wyższym w wieku 30-34 lata w ogólnej liczbie ludności w danej grupie wiekowej.

Sytuacja gospodarcza Polski zaklasyfikowała ją o pięć pozycji wyżej (12 lokata) niż w przypadku sytuacji społecznej; kraj nasz znalazł się w drugiej grupie razem z 11, w większości wysokorozwiniętymi, krajami. Okazało się, że w porównaniu ze średnią unijną grupa ta charakteryzowała się dobrą sytuacją na rynku pracy (niska stopa bezrobocia, najniższy przeciętny wskaźnik udziału bezrobotnych z wykształceniem wyższym, wysoki przeciętny wskaźnik zatrudnienia). Pozostałe cechy diagnostyczne były, niestety, na gorszym poziomie, co szczególnie dotyczyło odpadów komunalnych wytworzonych na 1 mieszkańca oraz wpływów z turystyki.

W celu zbadania powiązań pomiędzy pozycjami krajów UE w obu rankingach wyznaczono współczynnik korelacji $\tau$ Kendalla ${ }^{4}$, za pomocą którego można ocenić, czy występują zgodności uporządkowań badanych obiektów. Niski poziom tego - współczynnika $(0,1905)$ świadczy o słabych powiązaniach między miejscami w rankingach ${ }^{5}$. Porównanie przyna-

\footnotetext{
${ }^{4}$ Współczynniki $\tau$ Kendalla przyjmują wartości z przedziału $[-1,1]$. Im ich wartość jest bliższa 1, tym większa jest zgodność uporządkowań (Stanisz 2006).

${ }^{5}$ Potwierdza to również obliczona wartość współczynnika korelacji liniowej Persona $(0,1549)$ pomiędzy miernikami syntetycznymi dotyczącymi aspektów gospodarczych i społecznych.
} 
leżności krajów UE do grup typologicznych wykazało, że tylko 9 (32,1\%) z nich znalazło się w tych samych grupach - zarówno pod względem aspektów społecznych, jak i gospodarczych.

Tabl. 2. Klasyfikacja i grupy typologiczne krajów Unii Europejskiej ze względu na aspekty gospodarcze i społeczne w 2016 roku

\begin{tabular}{|c|c|c|c|c|c|}
\hline \multirow[b]{2}{*}{ Kraje } & \multicolumn{2}{|c|}{ Aspekty społeczne } & \multirow[b]{2}{*}{ Kraje } & \multicolumn{2}{|c|}{ Aspekty gospodarcze } \\
\hline & $\begin{array}{l}\text { wartość } \\
\text { miernika }\end{array}$ & numer grupy & & $\begin{array}{l}\text { wartość } \\
\text { miernika }\end{array}$ & numer grupy \\
\hline Malta & 0,6757 & \multirow{6}{*}{1} & Czechy & 0,7359 & \multirow{5}{*}{1} \\
\hline Niemcy & 0,6454 & & Szwecja & 0,7254 & \\
\hline Litwa & 0,6256 & & Rumunia & 0,7238 & \\
\hline Finlandia & 0,6225 & & Estonia & 0,7072 & \\
\hline Szwecja & 0,6201 & & Łotwa & 0,6989 & \\
\hline Cypr & 0,6179 & & Litwa & 0,6781 & \multirow{12}{*}{ II } \\
\hline Austria & 0,6035 & \multirow{9}{*}{ II } & Austria & 0,6688 & \\
\hline Grecja & 0,6020 & & Niemcy & 0,6502 & \\
\hline Francja & 0,5900 & & Węgry & 0,6449 & \\
\hline Estonia & 0,5839 & & Finlandia & 0,6351 & \\
\hline Łotwa & 0,5791 & & Bułgaria & 0,6209 & \\
\hline Słowenia & 0,5763 & & Polska & 0,6208 & \\
\hline Dania & 0,5759 & & Słowacja & 0,6119 & \\
\hline Belgia & 0,5747 & & Dania & 0,6042 & \\
\hline Czechy & 0,5738 & & Wielka Brytania & 0,5944 & \\
\hline Luksemburg & 0,5573 & \multirow{8}{*}{ III } & Malta & 0,5926 & \\
\hline Polska & 0,5507 & & Słowenia & 0,5922 & \\
\hline Węgry & 0,5359 & & Holandia & 0,5646 & \multirow{7}{*}{ III } \\
\hline Chorwacja & 0,5295 & & Luksemburg & 0,5591 & \\
\hline Wielka Brytania & 0,5294 & & Chorwacja & 0,5302 & \\
\hline Słowacja & 0,5246 & & Francja & 0,5245 & \\
\hline Holandia & 0,5146 & & Belgia & 0,5060 & \\
\hline Bułgaria & 0,5146 & & Włochy & 0,4997 & \\
\hline Irlandia & 0,5057 & \multirow{5}{*}{ IV } & Portugalia & 0,4806 & \\
\hline Portugalia & 0,4815 & & Irlandia & 0,4130 & \multirow{4}{*}{ IV } \\
\hline Włochy & 0,4790 & & Hiszpania & 0,3651 & \\
\hline Hiszpania & 0,4770 & & Cypr & 0,2833 & \\
\hline Rumunia & 0,4595 & & Grecja & 0,2681 & \\
\hline
\end{tabular}

We wcześniejszych rozważaniach przedstawiono wyniki klasyfikacji i grupowania krajów Unii Europejskiej ze względu na aspekty społeczne i gospodarcze. Chcąc ocenić sytuację społeczno-gospodarczą badanych krajów, zastosowano taksonomię wielokryterialną, dzięki której uwzględnione zostały wszystkie wybrane cechy diagnostyczne charakteryzujące jednocześnie oba badane aspekty (Nowak 1990; Malina 2004). Na podstawie 12 cech charakteryzujących sytuację społeczną i 10 cech charakteryzujących sytuację gospodarczą otrzymano siedem grup krajów o następującym składzie:

- grupa I: Austria, Belgia, Czechy, Dania, Estonia, Finlandia, Francja, Łotwa, Niemcy, Portugalia, Słowacja, Słowenia, Szwecja, Węgry, Wielka Brytania, Włochy;

- grupa II: Chorwacja, Malta, Rumunia;

- grupa III: Hiszpania, Holandia, Polska;

- grupa IV: Cypr, Luksemburg;

- grupa V: Bułgaria, Litwa;

- grupa VI: Grecja;

- grupa VII: Irlandia. 
Okazuje się, że o przynależności krajów do określonej grupy decydowała czasami nawet jedna cecha diagnostyczna, której poziom wyraźnie różnicował kraje pomiędzy sobą. Z uwagi na to zdecydowano się na wyznaczenie mierników, które można interpretować jako wagi określające relatywne znaczenie poszczególnych cech diagnostycznych. Mierniki te obliczono według wzoru:

$$
\omega_{j}=\frac{V_{j}}{\sum_{j=1}^{m} V_{j}} \cdot 100 \%
$$

gdzie:

$V_{j}$ - klasyczny współczynnik zmienności obliczony dla j-tej cechy diagnostycznej.

W badaniu sytuacji społeczno-gospodarczej krajów UE największe znaczenie mają: współczynnik przyrostu naturalnego (31,52\%), stopa bezrobocia długookresowego $(6,20 \%)$, udział energii ze źródeł odnawialnych w końcowym zużyciu energii brutto $(4,82 \%)$ i dług sektora instytucji rządowych i samorządowych, w \% PKB (4,31\%). W celu ukazania różnic w poziomie wymienionych cech w poszczególnych grupach obliczono wartości średnie w grupach i przedstawiono je na ryc. 1-4.

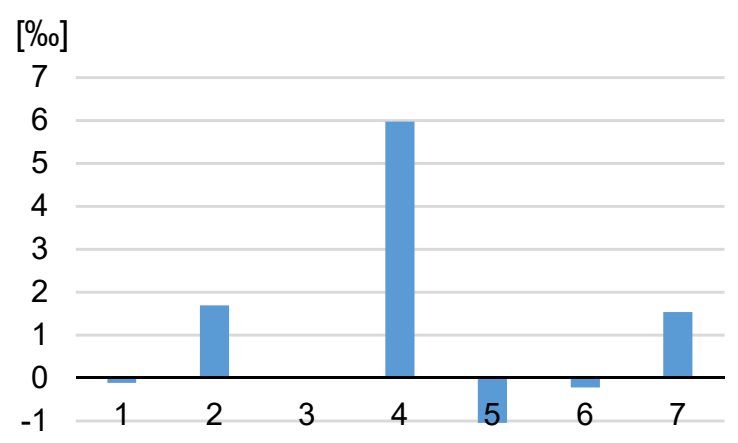

Ryc. 1. Średni poziom współczynnika przyrostu naturalnego w grupach typologicznych w 2016 roku

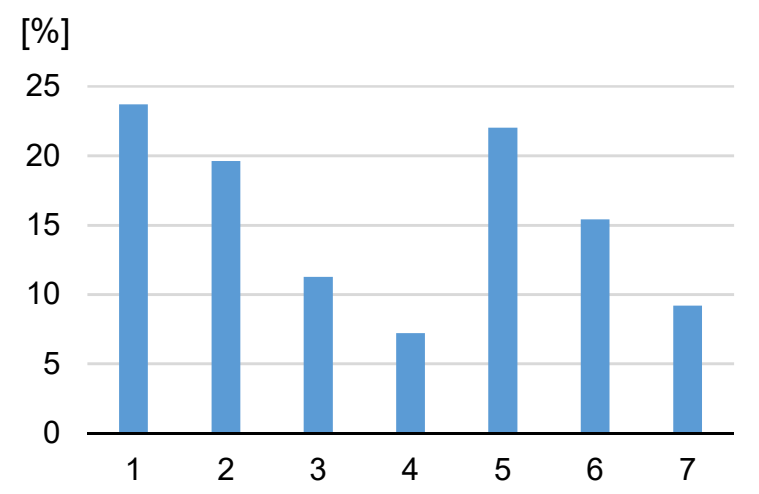

Ryc. 3. Średni udział energii ze źródeł odnawialnych Ryc. 4. Średni dług sektora instytucji rządowych i saw końcowym zużyciu energii brutto w grupach morządowych PKB w grupach typologicznych typologicznych w 2016 roku

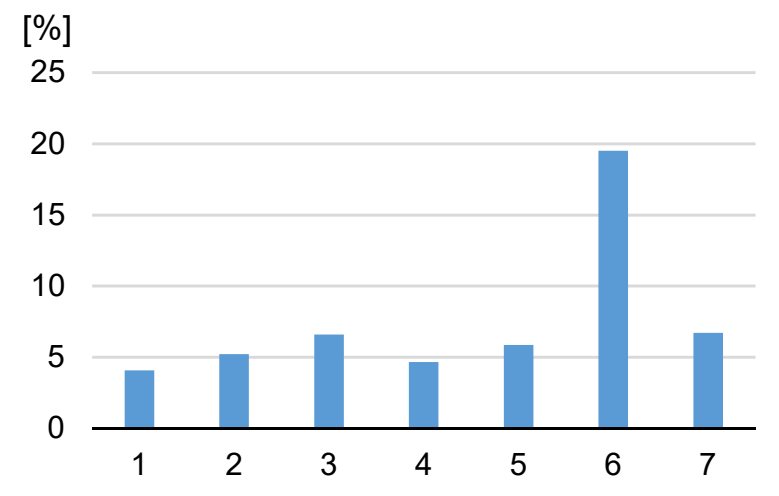

Ryc. 2. Średnia stopa bezrobocia długookresowego w grupach typologicznych w 2016 roku

[\% PKB]

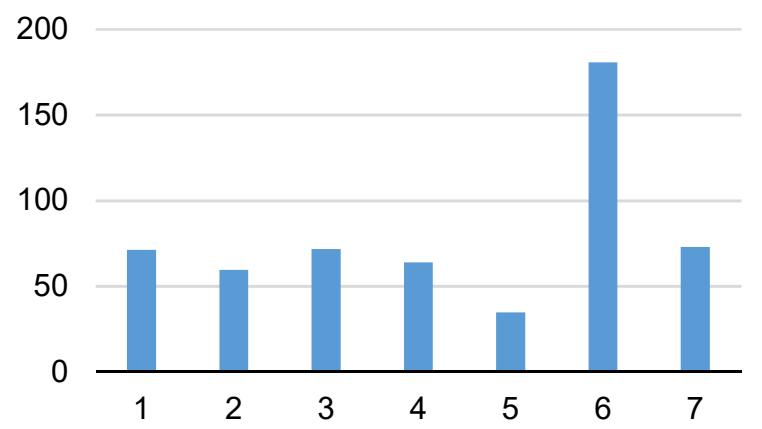

w 2016 roku 
Grupa I jest najbardziej liczna - znalazło się w niej aż 16 państw członkowskich o różnym stażu uczestnictwa w Unii Europejskiej. Szczegółowa analiza średniego poziomu cech diagnostycznych w poszczególnych grupach może stanowić podstawę wyjaśnienia, dlaczego np. w grupie I znalazły się kraje, o których można by sądzić, że mają odmienną sytuację społeczno-gospodarczą, np. Portugalia i Belgia. Ich przynależność do tej samej grupy była spowodowana przede wszystkim niskim poziomem współczynnika przyrostu naturalnego, niską stopą bezrobocia w większości krajów (szczególnie bezrobocia długookresowego), wysokim udziałem energii ze źródeł odnawialnych w końcowym zużyciu energii brutto oraz niższym, w porównaniu ze średnią unijną, wskaźnikiem zagrożenia ubóstwem lub wykluczeniem społecznym.

W grupie II znalazły się trzy kraje usytuowane na południu Europy, które przystąpiły do UE w latach 2004-2013. O zakwalifikowaniu krajów do tej grupy zadecydowały przede wszystkim: niska stopa bezrobocia długookresowego oraz bezrobocia osób z wykształceniem wyższym (oprócz Chorwacji), wysoki udział energii ze źródeł odnawialnych w końcowym zużyciu energii brutto (z wyjątkiem Malty), niski udział osób w wieku 30-34 lata posiadających wykształcenie wyższe (w \% ogółu ludności) w danej grupie wiekowej oraz niski udział, w porównaniu ze średnią unijną, liczby studentów na 10 tys. ludności.

Kolejną grupę (III) tworzą państwa położone w różnych częściach Europy, których przynależność do UE zaczęła się w 1957 roku (Holandia), a skończyła w 2004 roku (Polska). Obiekty w tej grupie charakteryzują się bardzo niskim współczynnikiem przyrostu naturalnego (wartości oscylują wokół zera) oraz małą liczbą zawartych małżeństw na 1000 ludności, przy współczynniku rozwodów przekraczającym średnią wartość unijną.

W grupie IV znalazły się dwa małe państwa (Cypr, Luksemburg), w których występują najwyższe współczynniki przyrostu naturalnego. Ponadto w krajach tych udział bezrobotnych z wykształceniem wyższym prawie dwukrotnie przewyższa średnią unijną, a średni udział energii ze źródeł odnawialnych w końcowym zużyciu energii brutto jest 2,5-krotnie niższy niż średni udział w UE.

Kolejną grupę (V) tworzą Litwa i Bułgaria - państwa, które przystąpiły do UE w latach 2004-2007. Charakteryzują się one przede wszystkim ujemnymi współczynnikami przyrostu naturalnego, wysokim udziałem energii ze źródeł odnawialnych w końcowym zużyciu energii brutto, niskim długiem sektora instytucji rządowych i samorządowych (w \% PKB) oraz dużą liczbą poszkodowanych w wypadkach śmiertelnych przy pracy na 100 tys. pracujących.

Pozostałe dwie grupy (VI, VII) tworzą skupienia jednoelementowe. Wydzielenie Grecji jako odrębnej grupy związane było z najwyższą wśród krajów UE stopą bezrobocia ogółem oraz bezrobocia długookresowego, a także bardzo niskim wskaźnikiem zatrudnienia osób w wieku 15-64 lata oraz najwyższym wśród krajów unijnych długiem sektora instytucji rządowych i samorządowych (w \% PKB). Pozytywnie ten kraj wyróżniał się pod względem liczby studentów szkół wyższych na 10 tys. ludności (najwyższy wskaźnik wśród krajów członkowskich) oraz opieki lekarza stomatologa - najniższy wskaźnik liczby ludności na 1 lekarza stomatologa wśród krajów UE.

W przypadku Irlandii poziom cech diagnostycznych, które posiadały największe znaczenie dyskryminacyjne, nie odbiegał znacznie od średniej unijnej, z wyjątkiem współczynnika przyrostu naturalnego na poziomie $1,53 \%$. Dopiero analiza pozostałych cech diagno- 
stycznych wykazała, że większość z nich była w Irlandii na poziomie znacznie różniącym się od średniej w pozostałych grupach. Do tych cech można zaliczyć: wskaźnik bardzo niskiej intensywności pracy w gospodarstwie domowym (najwyższy wśród krajów UE), wskaźnik rozwodów (najniższy wśród krajów członkowskich), wysokie zadłużenie sektora prywatnego (w \% PKB), mała liczba łóżek szpitalnych na 100 tys. ludności oraz wysoki udział osób w wieku 30-34 lata posiadających wykształcenie wyższe (w \% ogółu ludności) w danej grupie wiekowej.

\section{PODSUMOWANIE}

Dzięki zastosowanym w badaniu metodom możliwe było wyodrębnienie grup typologicznych krajów podobnych pod względem społecznym, gospodarczym i społeczno-gospodarczym. Na podstawie przeprowadzonych badań można stwierdzić, że kraje Unii Europejskiej, zarówno pod względem społecznym, jak i gospodarczym, stanowią zbiorowość niejednorodną, o czym świadczy m.in. zróżnicowanie taksonomicznych mierników rozwoju (współczynnik zmienności w przypadku aspektów społecznych wyniósł ok. 10\%, a w przypadku aspektów gospodarczych przekroczył 21\%). Okazało się, że kraje dobrze rozwinięte pod względem gospodarczym charakteryzują się niekorzystnymi wskaźnikami dotyczącymi np. sytuacji demograficznej, ochrony zdrowia czy przestępczości. Ponadto analiza rozkładu krajów według taksonomicznego miernika rozwoju wskazuje na asymetrię lewostronną bardzo słabą w przypadku aspektów społecznych (współczynnik skośności-0,034) i silną w przypadku aspektów gospodarczych $(-1,050)$, co jest zjawiskiem korzystnym, gdyż większość państw w UE w 2016 roku miała wartości taksonomicznego miernika powyżej średniej.

W celu dokonania oceny krajów UE jednocześnie pod względem sytuacji społecznej i gospodarczej zastosowano taksonomię wielokryterialną, dzięki której uwzględnione zostały wszystkie wybrane cechy diagnostyczne charakteryzujące jednocześnie oba badane aspekty. Otrzymano w ten sposób 7 grup krajów, które scharakteryzowano, dokonując szczegółowej analizy średniego poziomu cech diagnostycznych w poszczególnych grupach. Okazało się, że w wydzielonych grupach znalazły się państwa, o których można by sądzić, że mają odmienną sytuację społeczno-gospodarczą. Jednakże uzyskane wyniki udało się uzasadnić, przeprowadzając szczegółową analizę zarówno wartości taksonomicznego miernika rozwoju, jak i ważności cech diagnostycznych oraz ich średniego poziomu w poszczególnych grupach (Bąk i Wawrzyniak 2016).

Oczywiście otrzymane wyniki grupowania typologicznego mogą być dyskusyjne, ponieważ uzyskane zostały na podstawie wybranego, w sposób formalno-statystyczny, zestawu cech diagnostycznych. Przy zastosowaniu innych cech wyjściowych i metod ich doboru skład grup typologicznych mógłby ulec zmianie. Ponadto dużą trudnością w przeprowadzaniu tego typu analiz jest zebranie wiarygodnych i porównywalnych danych statystycznych. Okazuje się bowiem, że bazy danych urzędów statystycznych krajów Unii nie zawsze zapewniają pełne i aktualne informacje. Dlatego badania zaprezentowane w niniejszym opracowaniu należy przyjąć jako propozycję do dalszych badań z wykorzystaniem szerszego zakresu cech i metod. 


\section{PIŚMIENNICTWO}

Bąk I., Dembińska I., Cheba K., loppolo G., Kiba-Janiak M., Saniuk S., Szopik-Depczyńska K. 2017. The application of relative taxonomy to the study of disproportions in the area of sustainable development of the European Union. Land Use Policy 68C, 481-491.

Bąk I., Wawrzyniak K. 2016. Diagnoza sytuacji społeczno-gospodarczej Polski na tle krajów Unii Europejskiej. Wiad. Statyst. GUS 5, 63-82.

Chomątowski S., Sokołowski A. 1978. Taksonomia struktur. Prz. Statyst. 2, 217-225.

Eurostat. 2017. www.ec.europa.eu/eurostat/data/database, dostęp: 24.04.2018.

Kukuła K. 2000. Metoda unitaryzacji zerowanej. Warszawa, PWN, 60-92.

Malina A. 2004. Wielowymiarowa analiza przestrzennego zróżnicowania struktury gospodarki Polski według województw. Kraków, Wydaw. AE Krak., 60-62, 139-147.

Młodak A. 2006. Analiza taksonomiczna w statystyce regionalnej. Warszawa, Difin, 28-32.

Nowak E. 1990. Metody taksonomiczne w klasyfikacji obiektów społeczno-gospodarczych. Warszawa, PWE, 130-135.

Panek T. 2009. Statystyczne metody wielowymiarowej analizy porównawczej. Warszawa, SGH, 154-160.

Rocznik Statystyki Międzynarodowej 2017. 2017. Warszawa, GUS.

Stanisz A. 2006. Przystępny kurs statystyki z zastosowaniem STATISTICA PL na przykładach z medycyny. T. 1. Statystyki podstawowe. Kraków, Wydaw. StatSoft Polska, 313-314.

Walesiak M. 2011. Uogólniona miara odległości GDM w statystycznej analizie wielowymiarowej z wykorzystaniem programu R. Wrocław, Wydaw. UE Wroc., 16.

Streszczenie. Celem badań przeprowadzonych w artykule jest ocena sytuacji społecznogospodarczej krajów Unii Europejskiej oraz wyodrębnienie grup typologicznych krajów zbliżonych pod względem poziomu rozwoju. W artykule zastosowano dwa podejścia. Pierwsze z nich dotyczyło klasyfikacji krajów w aspekcie społecznym i aspekcie gospodarczym. Do tego wykorzystano metodę unitaryzacji zerowanej. Drugie podejście miało na celu podział krajów Unii Europejskiej na grupy typologiczne podobne pod względem cech charakteryzujących oba aspekty. W tym przypadku zastosowano taksonomię wielokryterialną. Dane do analizy zaczerpnięto z publikacji GUS oraz z Eurostatu. Na podstawie przeprowadzonych badań stwierdzono, że kraje dobrze rozwinięte pod względem gospodarczym często charakteryzują się niekorzystnymi wskaźnikami, dotyczącymi np. sytuacji demograficznej, ochrony zdrowia czy rynku pracy. 
